\title{
Studies on the Mode of Action of Soybean Lecithin Part 3. Effects on the Infection Process of Rice Blast Fungus, Pyricularia oryzae
}

\author{
Yasuo Homma*, Hiroharu TAKAhASHI** and Yutaka ARImoto*
}

\begin{abstract}
To clarify the mode of action of soybean lecithin (SL), we studied the effect on morphology of Pyricularia oryzae by using the onion epidermal strip method. SL at $500 \mathrm{ppm}$ induced an abnormal structure at the surface of the conidium or the germ tube. From observation $24 \mathrm{hr}$ after inoculation, SL did not inhibit appressorial formation at $5 \mathrm{ppm}$, but $500 \mathrm{ppm}$ or more SL inhibited $86.2 \%$ or more appressorial formation. $500 \mathrm{ppm}$ SL also induced a morphological abnormality in germ tube with its branching at the tip and consequently inhibited appressorial formation. Besides, SL inhibited 96\% appressorial penetration at $5 \mathrm{ppm}$. The inhibition of appressorial penetration is the most characteristic action of SL.
\end{abstract}

(Received June 13, 1991)

Key words : Pyricularia oryzae, onion epidermal strip methods, soybean lecithin.

\section{INTRODUCTION}

It was found first by Homma ${ }^{1)}$ that lecithin obtained from soybean seeds in the process of soybean oil production effectively controlled rice blast disease on seedlings. Thereafter, the lecithin showed an excellent preventive effect against powdery mildews of cucumber, eggplant, pumpkin and pepper in field tests at several agricultural experimental stations. In order to develop it as a pest-control for wider use against various plant diseases, we have tried to clarify the mode of action of soybean lecithin (SL) against the growth stage of cucumber powdery mildew, Sphaerotheca fuliginea ${ }^{2,7)}$ and rice blast, Pyricularia oryzae $e^{4}$. SL induced a membrane-like substance at the surface of the hyphal tips of $S$. fuliginea and also caused shrinkage of newly-formed conidia and conidiophores ${ }^{7}$.

The authors found that the rice blast fungus, Pyricularia oryzae, can complete almost all growth stages on stripped epidermal cells of onion bulbs ${ }^{6}$, such as conidial germination, appressorial formation, appressorial penetration, and conidiophore and conidial formation. K. Tomono et al.clarified that citrus melanose fungus, Diaporthe citri did also complete almost all growth stages on stripped epidermal cells of onion bulbs, and that the conidia formed on the cells have ability to infect and induce melanose spots on young citrus leaves ${ }^{10)}$.

In addition, Y. Iwata et al. also showed that Botrytis cinerea penetrated in epidermal cells of onion bulbs and elongated hypha in the cells ${ }^{8}$. As mentioned above, this method was adapted to observation of growth stages of some pathogenic fungi and we could easily observe the behaviors of above mentioned fungi not only on epidermal cells but also in the cells. In addition the method is characteristic in that we are able to observe the same position at a given interval under the optical microscope. This

* The Institute of Physical and Chemical Research, Hirosawa 2-1, Wako-shi, Saitama 351, Japan 理化学研究 所

** National Institute of Agro-environmental Sciences, Ministry of Agriculture, Forestry and Fishery, YatabeMachi, Tsukuba, Ibaraki 305, Japan＼cjkstart農業環境技術研究所 
method can be applied to practical bioassay of fungicides. Therefore, the authors have proposed that it was called the onion epidermal strip method ${ }^{6}$. We could show that the method can be used for observing the effect of chemicals on growth stages of pathogenic fungi ${ }^{6}$. For these reasons, we tried to study the effect of soybean lecithin on morphological changes of Pyricularia oryzae by using this method.

\section{MATERIALS AND METHODS}

Fungus and chemicals. Pyricularia oryzae Cavara as a test organism was cultured on yeaststarch (YS) slant media for 8 days at $25^{\circ} \mathrm{C}$. Conidial suspension prepared from the culture was adjusted to $8 \times 10^{6}$ conidia $/ \mathrm{ml}$, and the suspension was mixed with the same volume of a given concentration of lecithin solution. The lecithin (SL) from Ajinomoto Co., Ltd. was used at some concentrations from 0.1 to $1,000 \mathrm{ppm}$. Namely, $0.2 \mathrm{~g}$ SL was dissolved in $0.8 \mathrm{ml}$ ethanol $50 \%$ solution and was adjusted to 2,000 ppm as stock solution. After then, the stock solution was diluted with sterilized water.

Morphological observation in the growth stages of $\boldsymbol{P}$. oryzae The conidial suspension containing SL was placed on stripped epidermal cells of onion bulbs according to the onion epidermal strip method $\left.{ }^{6}\right)$ and the samples were kept on a wet filter paper in a moist chamber $(100 \% \mathrm{RH})$ at $25^{\circ} \mathrm{C}$. Each growth stage of $P$. oryzae was observed at a given intervals after treatment under an optical microscope $(\mathrm{OM})$ or a scanning electron microscope (SEM). Also SL solution $(2,000 \mathrm{ppm})$ was sprayed onto rice leaves (3.5 leaf stage). After drying, conidial suspensions were dropped onto the youngest leaf, and the leaf was kept in a moist chamber $(100 \% \mathrm{RH})$ at $25^{\circ} \mathrm{C}$. After $24 \mathrm{hr}$, the leaf blades were fixed with formalin vaper, and then coated and observed under the $\mathrm{SEM}^{7}$.

\section{RESULTS}

\section{Effect of SL on conidia and germ tubes}

Plate I-1A and 2A show conidial germination in water without SL (Control). In conidia (1B) and germ tubes (2B) treated with $500 \mathrm{ppm}$ SL, abnormal structure were observed at the base of conidium (Plate I-1B, arrow) and near the tip of germ tube (Plate I-2B), compared with them (1A, 2A) without SL treatment. This was observed only at conidium or germ tube with SL treatment.

\section{Effect of $S L$ on appressorial formation}

Plate II-3A shows the whole image of appressorial formation of conidia without treatment under SEM. Nine conidia in the photograph germinated and four conidia among them formed appressoria. On the other hand, Plate II-3B shows the image of the $500 \mathrm{ppm}$ SL treatment. As shown in this photograph, conidial germination was not inhibited at all by $500 \mathrm{ppm}$ SL treatment, while appressorial formation did not occur in the field of view under a SEM. Enlarged photographs taken by SEM are shown in Plate II-4A (non-treated conidia) and 4B (500 ppm SL treatment). In Plate II-4A, conidia began to form typical appressoria $3 \mathrm{hr}$ or more after inoculation. On the other hand, as shown in Plate II-4B, $500 \mathrm{ppm}$ or more SL suppressed appressorial formation to $86.2 \%$ (Table 1) or more. Plate II-5A shows an appressorial formation of the fungus on non-treated rice leaf. Plate II-5B shows the conidia treated with 2,000 ppm

Table 1. The concentrations of soybean lecithin inducing morphological abnormality of Pyricularia oryzae on stripped epidermal cells of onion bulb

\begin{tabular}{|c|c|c|c|c|c|c|c|}
\hline \multicolumn{2}{|c|}{ Soybean lecithin } & \multicolumn{6}{|c|}{ Growth stages } \\
\hline \multirow{3}{*}{$\begin{array}{l}\text { Conc. } \\
\text { (ppm) }\end{array}$} & Components & Conidium & Germtube & & pha & Appre & sorium \\
\hline & \multirow{2}{*}{$\begin{array}{l}\text { Phospholipids } \\
\text { (ppm) }\end{array}$} & \multirow{2}{*}{$\begin{array}{c}\text { Abnormal } \\
\text { structure }\end{array}$} & \multirow{2}{*}{$\begin{array}{c}\text { Abnormal } \\
\text { structure }\end{array}$} & \multicolumn{2}{|c|}{ Abnormal } & \multicolumn{2}{|c|}{ Inhibition (\%) } \\
\hline & & & & Branch & Elongation & Formation & Penetration \\
\hline 5 & $4.68^{\mathrm{a})}$ & - b) & - & - & - & 0.0 & 95.9 \\
\hline 500 & $468.00^{\mathrm{a})}$ & $+^{b)}$ & + & + & + & 86.2 & 100.0 \\
\hline
\end{tabular}

a) The values are estimated by an analytical data of Ajinomoto Co., Ltd.

b) -: no morphological change, + : observed morphological change. 
SL, germinated but did not form appressoria on the rice leaf. Appressorial formation was also inhibited by SL on rice leaf as well as on onion epidermal cells.

\section{Effect of $S L$ on penetration from appressorium}

Five hundred ppm or more SL inhibited appressorial formation of rice blast fungus. As shown in Plate III-6A, granulation in onion epidermal cells beneath conidia was observed about $24 \mathrm{hr}$ after inoculation. On the other hand, as shown in Plate III-6B, conidia treated with 500 ppm SL germinated and elongated germ tubes which abnormally branched at the tip, and scarcely formed appressoria. Granulation in onion epidermal cells without SL treatment became severer and infection pegs developed. Also, penetration rate increased with passage of inoculation time (Plate III-7A). On the other hand, as shown in Plate III-7B, penetration from the appressoria was inhibited completely when treated with $5 \mathrm{ppm}$ or more SL on the epidermal cells. As the method has a merit that allows repeated observations of the same specimen at a given interval, we can decide whether the penetration has been completed or not.

\section{Effect of SL on hyphal elongation}

Plate III-8A shows the whole image of hyphal elongation on onion stripped epidermal cells without SL treatment, and Plate III- $8 \mathrm{~B}$ shows the hyphal elongation when treated with the $500 \mathrm{ppm}$ SL. Since hyphae elongated here and there on the cells, it is suggested that $500 \mathrm{ppm}$ SL did not inhibit hyphal elongation.

\section{DISCUSSION}

Using the onion epidermal strip method ${ }^{6}$, the effect of SL on the penetrating forms of rice blast fungus was investigated.

When 2,000 ppm SL was directly applied to conidia of Sphaerotheca fuliginea, the conidial germination was inhibited $77 \%{ }^{2}$. However, conidial germination of Pyricularia oryzae was not inhibited by treatment with the same concentration of $\mathrm{SL}^{3,4,9)}$. It is noticeable that conidia or germ tubes of $P$. oryzae treated with $500 \mathrm{ppm}$ SL locally formed the same abnormal structure as observed at the hyphal tips of S. fuliginea ${ }^{7}$ treated with SL. The structure was formed on the surface of these fungal cells that had elongated. Although SL induced this structure on conidium and germ tube at $500 \mathrm{ppm}$ or more, it did not show any inhibitory action against germination and hyphal elongation of $P$. oryza $e^{3,4}$. Appressorial formation from germ tubes was significantly inhibited by $500 \mathrm{ppm}$ or more SL treatment. Inhibition of the appressorial formation was also observed on the leaves of rice seedlings pre-sprayed with 2,000 ppm SL.

On stripped onion epidermal cells, granulation in onion cells beneath appressoria was often observed $^{6}$ ) before penetration, suggesting that the onion epidermal cells react to the attack in a living state of cells. In $500 \mathrm{ppm}$ SL treatment, abnormal germ tube with its branching at the tip were often observed. It is not clear why SL induces the abnormal branching at tips of germ tubes.

The effect of SL on the penetration of this fungus was observed at as low as $5 \mathrm{ppm}^{3-5}$. As appressorial formation was significantly inhibited at $500 \mathrm{ppm}$, the concentration required to inhibit penetration is about one-hundredth of that for inhibition of appressorial formation. Other growth stages were not inhibited even at $1,000 \mathrm{ppm}$. The inhibition of penetration of $P$. oryzae was the most characteristic action of SL. Anti-blast chemicals such as tricyclazole, pyroquilon, tetrachlorophthalide and pentachloro-benzyl alcohol also have a characteristic inhibitory action only against penetration ${ }^{11}$. On the premise that melanization of the appressoria correlates to penetration, it was explained that these chemicals act as a melanin biosynthesis inhibitor to inhibit the formation of penetration hypha.

In the SL treatment, appressorial formation and its melanization were not inhibited, but penetration from an appressorium was inhibited at the low concentration of $5 \mathrm{ppm}$. So, it was suggested that the action of SL differed from the above-mentioned chemicals. Judging from the inhibitory concentration of $\mathrm{SL}$ in penetration and appressorial formation at $5 \mathrm{ppm}$ and at $500 \mathrm{ppm}$ respectively, it might be assumed that SL acts as inhibitor against the penetration from appressoria. Therefore, SL can cut a part of life cycles of $S$. fuliginea or $P$. oryzae and suppress cucumber powdery mildew and rice blast disease. 
SL is composed of phospholipids, namely phosphatidyl choline, phosphatidyl ethanolamine, phosphatidyl inositol and phosphatidyl serine, and these are main components of biomembranes. SL inhibited the penetration or appressorial formation of $P$. oryzae, besides induced morphological abnormality on conidia or germ tube of $P$. oryzae and S. fuliginea. These findings mean very important significance. As the plant protection from now will require the safe materials prior to all, we hope that SL will be wider applied in this area.

The authors wish to thank Miss K. Kobayashi for assistance on this work.

\section{Literature cited}

1. Homma, Y. (1978). Further development of agricultural chemicals. In Recent Advances in Phytopathological Chemistry (Tomiyama, K. et al. eds.). Nagoya, pp. 173-185.

2. Homma, Y., Arimoto, Y. and Misato, T. (1984). Studies on the mode of action of soybean lecithin. Part 2. Effect of soybean lecithin on developmental stages of cucumber powdery mildew fungus (Sphaerotheca fuliginea). Ann. Phytopath. Soc. Japan $50: 31-38$.

3. Homma, Y., Arimoto, Y. and Misato, T. (1979). The mode of action of soybean lecithin against pathogenic fungi. 9th Int. Congr. Plant Protect. 924 (Abstr.).

4. Homma, Y., Arimoto, Y. and Misato, T. (1980). Effect of soybean lecithin on each stage of rice blast fungus (Pyricularia oryzae Cav.) in its life cycle. J. Pesticide Sci. 5: 611-613.

5. Homma, Y., Arimoto, Y. and Misato, T. (1982). Morphological alteration of plant pathogens by soybean lecithin. 5th Int. Congr. Pesticide Chemistry IIIa-8 (Abstr.).

6. Homma, Y., Arimoto, Y., Takahashi, H. and Misato, T. (1983). Observation of the various growth stages of rice blast fungus (Pyricularia oryzae Cavara) by onion epidermal strip method. J. Pesticide Sci. 8 : 371377 .

7. Homma, Y., Takahashi, H., Mizuno, H. and Misato, T. (1977). Effect of soybean lecithin on cucumber powdery mildew, Sphaerotheca fuliginea, at various growth stages. J. Pesticide Sci. 2: 33-40.

8. Iwata, Y., Homma, Y., Arimoto, Y. and Shimoyama, M. (1986). Observation of the conidial germination and hyphal penetration of Botrytis cinerea by the onion epidermal strip method. Ann. Phytophath. Soc. Japan $52: 475-477$.

9. Shimoyama, M., Tabata, H., Homma, Y., Arimoto, Y. and Misato, T. (1983). The characteristic action of soybean lecithin against plant pathogens. 10th. Int. Congr. Plant Protect. Proceedings III 6F-R28.

10. Tomono, K., Arimoto, Y., Homma, Y. and Misato, T. (1979). Observations of growth stages of Diaporthe citri on epidermal strips of onion bulb. Ann. Phytopath. Soc. Japan 45 : 444-452.

11. Woloshuk, C.P. and Sisler, H.D. (1982). Tricyclazole, pyroquilon, tetrachlorophthalide, PCBA, coumarin and related compounds inhibit melanization and epidermal penetration by Pyricularia oryzae. J. Pesticide Sci. 7: 161-166.

\section{和 文 摘 要}

\section{本間保男・高橋広治・有本 裕：大豆レシチンの作用機構に関する研究 第 3 報 イネいもち病菌の感染過程に及浪 す影響}

大豆レシチンの作用機構を解明するため, タマネギりん片剝離表皮検定法を用い, イネいもち病菌の形態に及ぼす影 響を検討した。接種 24 時間後の観察によると, $5 \mathrm{ppm}$ 大豆レシチンはイネいもち病菌の付着器形成を阻害しなかった が，付着器侵入をほぼ完全に抑制した。その $500 \mathrm{ppm}$ はイネいもち病菌の分生胞子側面あるいは発芽管側面に異状構 造物の形成を誘導し, 付着器形成を著しく抑制し, その上発芽管先端は二分岐するという形態異常が認められた。また, $2,000 \mathrm{ppm}$ 大豆レシチンを処理したイネ葉上でも付着器形成が抑制された。しかし, 分生胞子発芽や菌系伸長は 1,000 あるいは 2,000 ppm でも抑制されなかったので，大豆レシチンの抑制効果は，いもち病菌の生育過程のうち付着器侵 入の抑制にあると判断された。 


\section{Explanation of plates}

\section{Plate I}

Effect of soybean lecithin on conidial germination of $P$. oryzae.

1A, 2A. Conidial germination non-treated with SL on the stripped onion epidermal cells $3 \mathrm{hr}$ after inoculation.

1B, 2B. Conidial germination treated with $500 \mathrm{ppm}$ SL $3 \mathrm{hr}$ after inoculation. c: conidium, gt: germ tube, arrow: abnormal structure, bar: $5 \mu \mathrm{m}$. The pictures with scanning electron microscope (SEM).

\section{Plate II}

Effect of soybean lecithin on appressorial formation of P. oryzae.

3A, 4A. Whole image of appressorial formation non-treated with SL on stripped onion epidermal cells $4 \mathrm{hr}$ after inoculation. a: appressorium, bar: $50(3 \mathrm{~A}), 5$ and $2.5(4 \mathrm{~A}) \mu \mathrm{m}$, picture with SEM.

3B, 4B. Whole image of appressorial formation treated with $500 \mathrm{ppm}$ SL on stripped onion epidermal cells $4 \mathrm{hr}$ after inoculation. arrow: germ tube non-formed appressorium, bar: 50 (3B) and $5(4 \mathrm{~B}) \mu \mathrm{m}$, picture with SEM.

5A. Appressorium non-treated with SL on rice leaf 1 day after inoculation. a: appressorium, bar: $2.5 \mu \mathrm{m}$, picture with SEM.

5B. Germ tube treated with 2,000 ppm SL on rice leaf 1 day after inoculation. arrow: germ tube non-formed appressorium, bar: $5 \mu \mathrm{m}$, picture with SEM.

\section{Plate III}

Effect of soybean lecithin on penetration from appressorium of $P$. oryzae.

6A. Granulation of stripped onion epidermal cells $24 \mathrm{hr}$ after inoculation. a: appressorium, g: granulation, bar: $10 \mu \mathrm{m}$, picture with optical microscope (OM).

6B. Branched germ tube treated with $500 \mathrm{ppm}$ SL on stripped onion epidermal cells $24 \mathrm{hr}$ after inoculation. arrow: branched germ tube, bar: $10 \mu \mathrm{m}$, picture with SEM.

7A. Penetration from appressorium non-treated with SL into stripped onion epidermal cells $24 \mathrm{hr}$ after inoculation. ap: appressorial penetration, bar: $10 \mu \mathrm{m}$, picture with SEM.

7B. Appressoria treated with $5 \mathrm{ppm}$ SL on stripped onion epidermal cells $24 \mathrm{hr}$ after inoculation. arrow: appressorium non-penetrated, bar: $10 \mu \mathrm{m}$, picture with SEM.

Effect of soybean lecithin on hyphal elongation of $P$. oryzae.

8A. Whole image of hyphal elongation non-treated with SL on stripped onion epidermal cells 4 days after inoculation. arrow: hyphal elongation, bar: $10 \mu \mathrm{m}$, picture with SEM.

8B. Whole image of hyphal elongation treated with $500 \mathrm{ppm} \mathrm{SL}$ on stripped onion epidermal cells 4 days after inoculation. arrow: hyphal elongation, bar: $10 \mu \mathrm{m}$, picture with SEM. 


\section{Plate I}
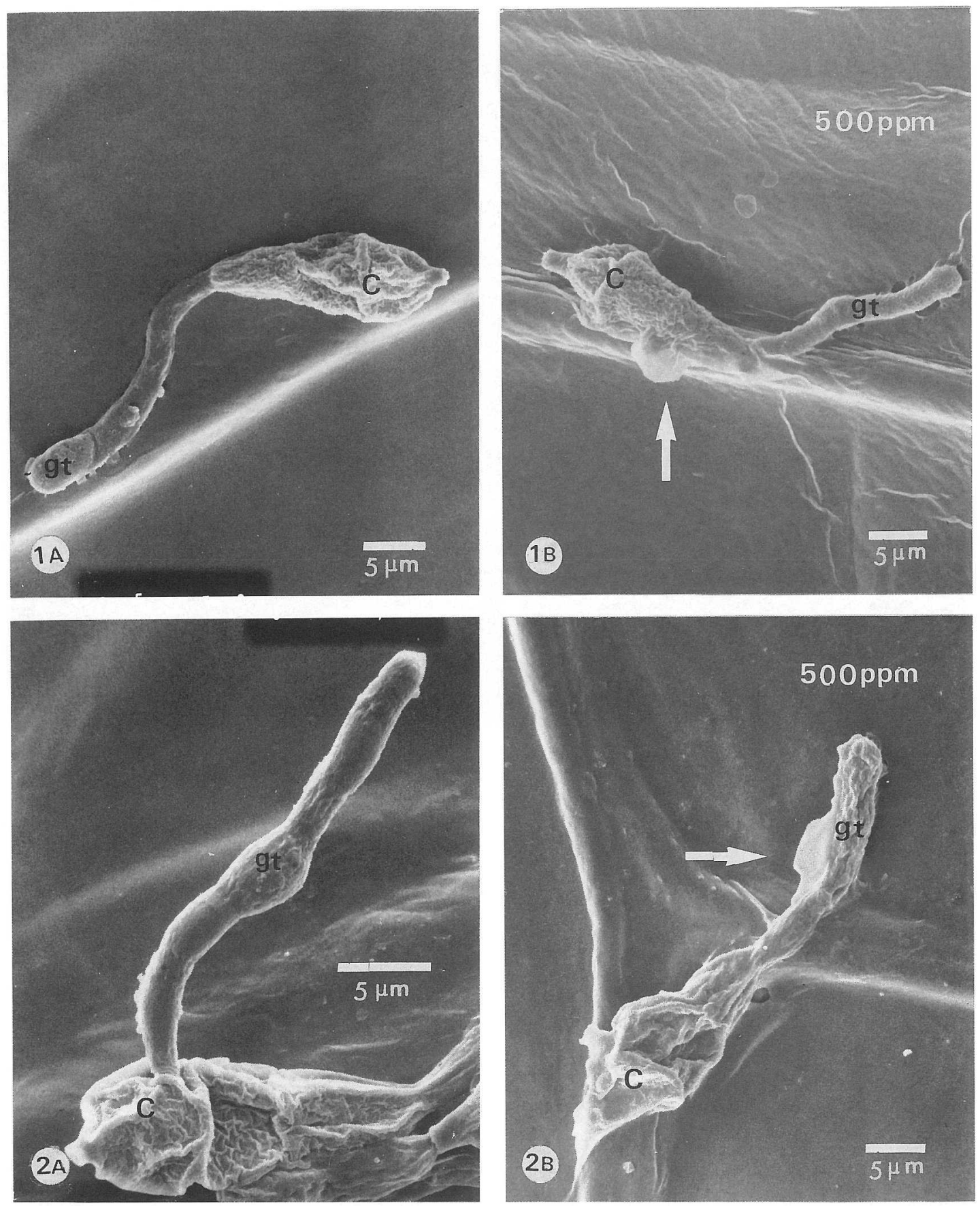


\section{Plate II}
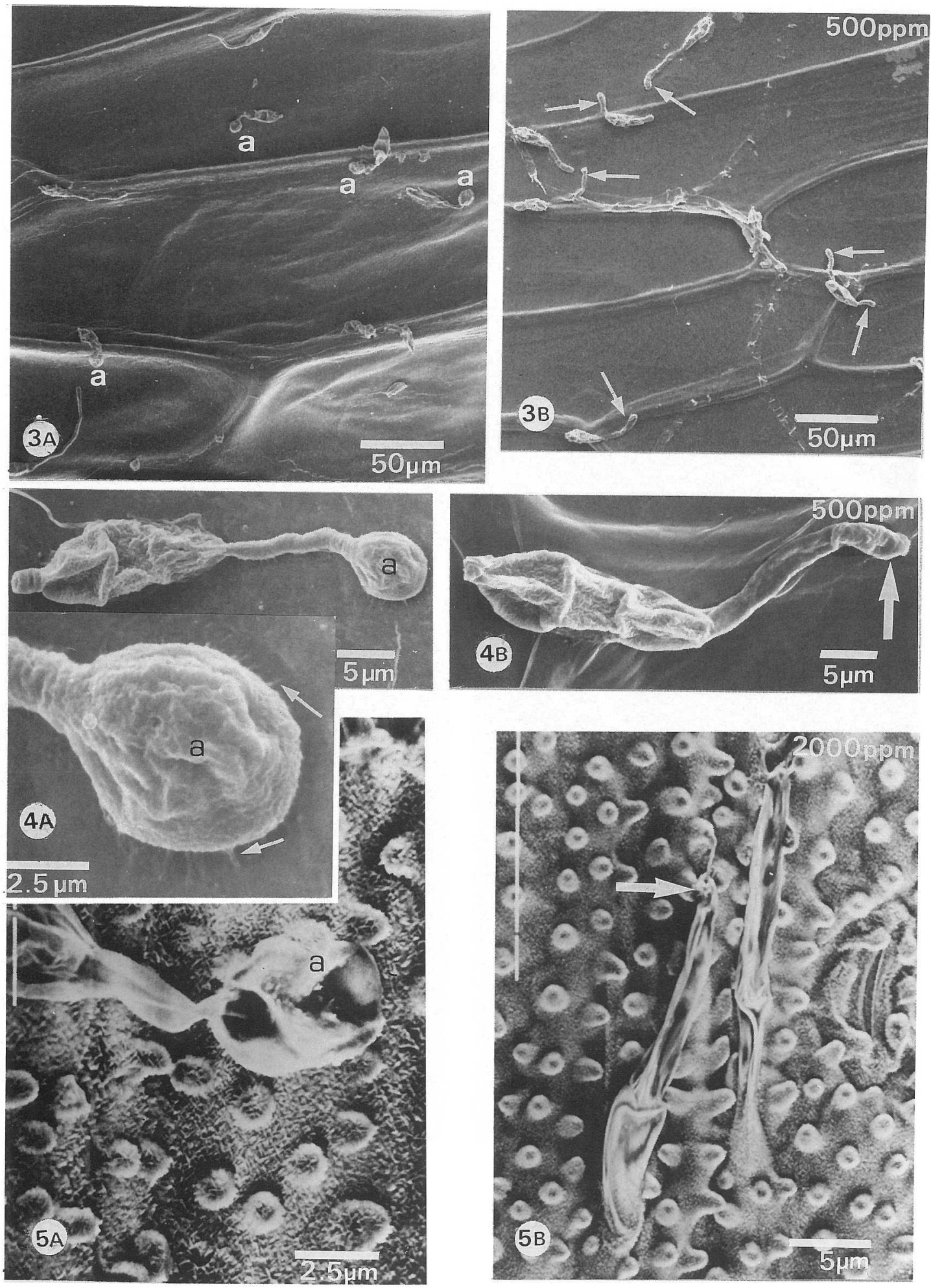


\section{Plate III}
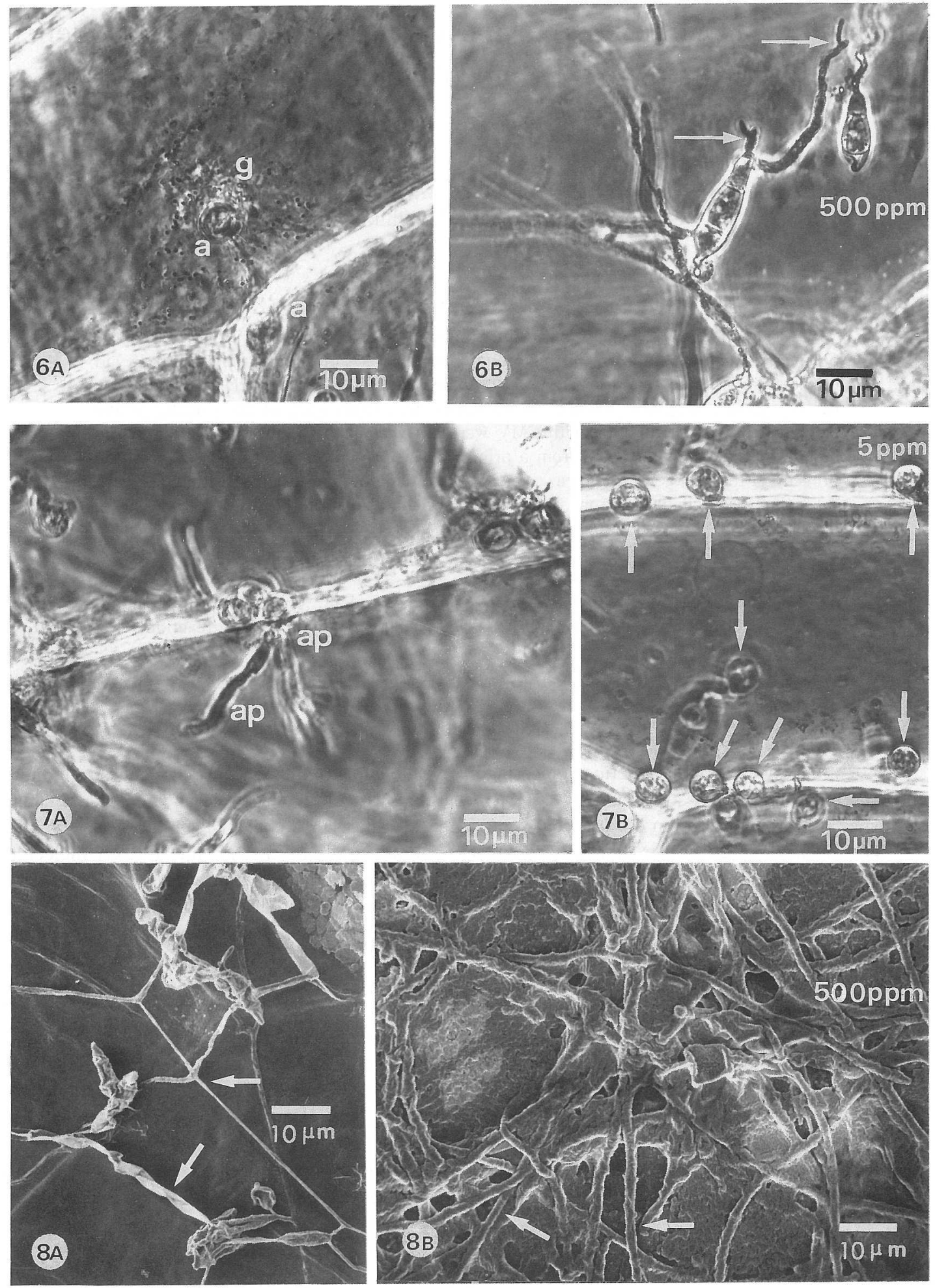

10 ynn

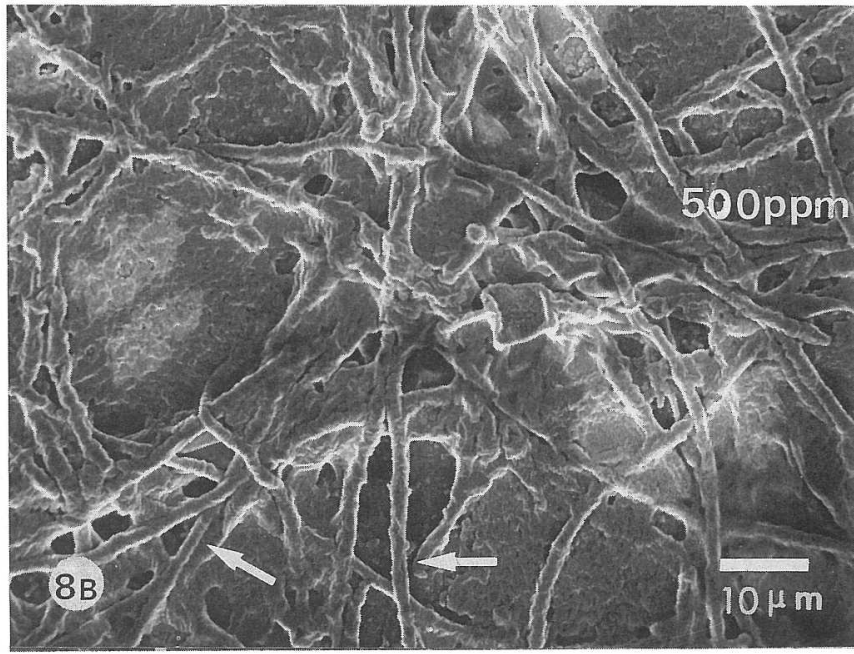

